\title{
Assessment of spatial distribution of aridity indices in Raya valley, northern Ethiopia
}

\author{
Mewcha Amha Gebremedhin ${ }^{1} \cdot$ Gebrerufael Hailu Kahsay ${ }^{1} \cdot$ Hailemariam Gebrewahed Fanta ${ }^{1}$
}

Received: 4 December 2016 / Accepted: 1 November 2018 / Published online: 8 November 2018

(c) The Author(s) 2018

\begin{abstract}
Aridity is a risk with the threat of desertification because of erratic precipitation and prolonged droughts. Aridity indices are often used for the climate-based land classification and monitoring droughts. Hence, this study aimed at analysis of the spatial distribution of aridity indices in Raya valley, northern Ethiopia. Meteorological data from eight meteorological stations located throughout the study area were used to compute the three aridity indices employed: the De Martonne aridity index $\left(I_{\mathrm{DM}}\right)$, the Pinna combinative index $\left(I_{\mathrm{P}}\right)$, and the Food and Agriculture Organization aridity index $\left(I_{\mathrm{FAO}}\right)$. Each aridity index value was computed at each station. Then, once the statistical properties of each aridity index at each station were assessed, inverse distance-weighted geographic information system interpolation technique was used for the spatial estimation of the aridity indices. The three indices indicated a high coefficient of determination which in common revealed the area prone to dry and semi-dry risk. However, $I_{\mathrm{DM}}$ was found more appropriate for the considered area since it defines more the climate of each location using seven classes, and it can be computed at specific season and month. The annual, seasonal, and monthly aridity indices of $I_{\mathrm{DM}}$ showed high spatial variability of aridity index. The spatial distribution of the $I_{\mathrm{DM}}$ underlined irrigation requirements in the northern east part of the study area. This analysis may be helpful for the utilization of water resources and irrigation systems of the study area.
\end{abstract}

Keywords Aridity indices $\cdot$ Raya valley $\cdot$ Spatial distribution

\section{Introduction}

Nowadays, the decrease in quantity of water and its fluctuating distribution patterns can seriously affect the economy of the globe (Moral et al. 2015), and this can happen because of climate change impact. Climate change is a change in average weather conditions which persists for decades or longer (IPCC 2012). Global climate variability and change, which are caused by natural processes as well as anthropogenic factors, are the most thoughtful problems that affect the whole world currently and for the future (Kenny et al. 2001; Hrnjak et al. 2013; IPCC 2007). This change may occur across the whole or may be limited to a specific region. The rainfall, sunshine, wind, humidity, and temperature are the factors that determine the climate at a location. Therefore, these climate variability and change are expected to alter regional

Mewcha Amha Gebremedhin

mewcha.amha@mu.edu.et

1 Institute of Geo-Information and Earth Observation Science, Mekelle University, Mekele, Ethiopia conditions. According to IPCC (2007) report, climate change and climate variability could affect negatively in the east African highlands. Small changes in climate variables can cause considerable changes in water resources operation specially in developing nations like Ethiopia which have been challenged to satisfy the most urgent water needs.

Droughts have become a recurrent phenomenon in many regions of the world affecting more and more ecosystems and society. Therefore, climate indices become good indicator for analyzing climate change (Zubler et al. 2014). Climate indices, function of two or more climate variables, are diagnostic tools used to define the state of climate system, and the understanding of various climate mechanisms has been improved based on several climate variables (Deniz et al. 2011). Climate indices facilitate the interpretation of projected climate change impacts for many sectors in society (Zubler et al. 2014). Climate indices studies have also proved that they are very important to forecast agricultural production. Among the numerous climatic indices, the aridity indices are widely used for the climate-based land classification 
and monitoring droughts (Arora 2002; Hrnjak et al. 2013; Moral et al. 2015).

Fields like agriculture and water supply can have severe damage because of aridity increment. Such condition can be a warning signal affecting plant growth and distribution when associated with temperature. This is the main reason why many scholars have become increasingly worried about the frequent occurrence of this phenomenon (Croitoru et al. 2013).

Agriculture is the most and largest production sector of Ethiopian economy. However, water shortage is one of the major problems in the country. As a result the country experienced droughts in different years with different magnitudes. Raya valley is huge agricultural corridor of Tigray region, but often exposed to water shortage. Though, studying aridity distribution is a key for agricultural management (Croitoru et al. 2013), the spatial distribution of aridity indices in Raya valley is not studied yet. Therefore, this paper focused to assess the spatial distribution of aridity indices in Raya valley.

\section{Study area}

The area considered for this study, Raya Valley, is located in northern part of Ethiopia between latitude of $12^{\circ} 05^{\prime}-12^{\circ} 55^{\prime} \mathrm{N}$ and longitude of $39^{\circ} 21^{\prime}-39^{\circ} 55^{\prime} \mathrm{E}$ (Fig. 1).
The valley consists of two sub-watershed, namely Alamata and Mohoni sub-watersheds. It is bounded by the Korem Mountains in the west, the Chercher Mountains in the east, and in the south by low east-west surface divide near Kobo town separating the Alamata sub-watershed from the Golina sub-watershed to the south. The valley considered is part of interconnected valleys of the Ethiopian rift valley system and covers an area of about $2515 \mathrm{~km}^{2}$. It consists of three major drainage systems emerging dominantly from the western mountain ranges and partly from the eastern margin. The area is characterized by a bimodal rainfall pattern with a peak in August. The variability in altitude of the area brings variability in rainfall and temperature. The valley is characterized by scarcity of surface water and rainfed agricultural practices by diverting flush floods from the western side of the mountain (Fenta et al. 2015).

\section{Materials and methods}

\section{Data sources}

Digital elevation model (DEM) with $30 \mathrm{~m}$ resolution used for delineating the study area and creating layers relating to topography was from Shuttle Radar Topographic Mission (SRTM). Meteorological data for eight stations that constitute the study area were obtained from Ethiopian national

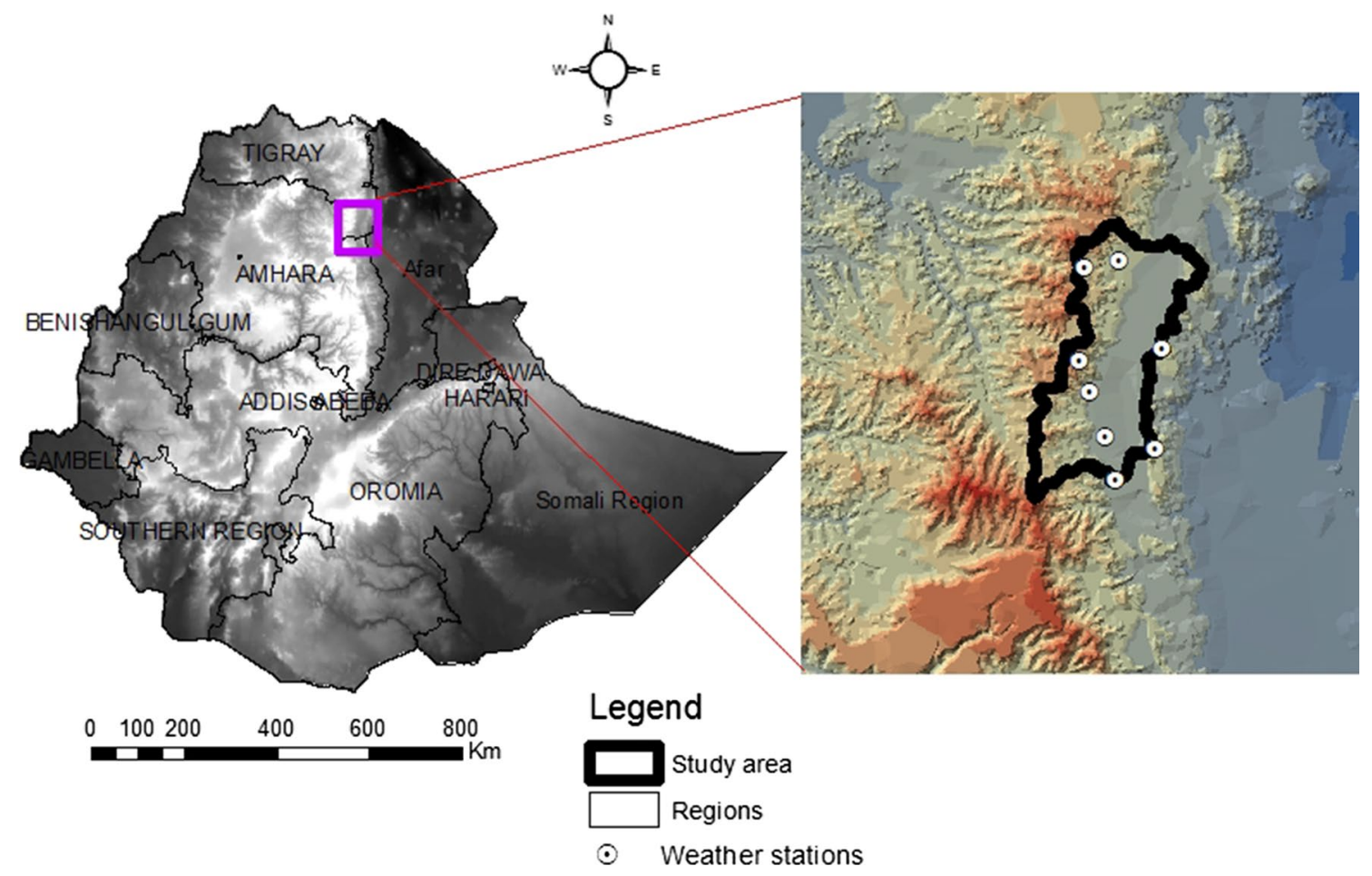

Fig. 1 Location map of the study area

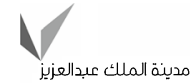

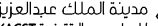
Springer 
Table 1 Geographic coordinates and altitude of meteorological stations

\begin{tabular}{llll}
\hline Station & Longitude & Latitude & Altitude $(\mathrm{m})$ \\
\hline Alamata & $39^{\circ} 42^{\prime} 51^{\prime \prime}$ & $12^{\circ} 25^{\prime} 23^{\prime \prime}$ & 1547 \\
Kobo & $39^{\circ} 37^{\prime} 60^{\prime \prime}$ & $12^{\circ} 07^{\prime} 60^{\prime \prime}$ & 1524 \\
Korem & $39^{\circ} 30^{\prime} 53^{\prime \prime}$ & $12^{\circ} 30^{\prime} 51^{\prime \prime}$ & 2466 \\
Maichew & $39^{\circ} 32^{\prime} 01^{\prime \prime}$ & $12^{\circ} 47^{\prime} 03^{\prime \prime}$ & 2438 \\
Zobel & $39^{\circ} 44^{\prime} 54^{\prime \prime}$ & $12^{\circ} 10^{\prime} 15^{\prime \prime}$ & 2139 \\
Chercher & $39^{\circ} 46^{\prime} 01^{\prime \prime}$ & $12^{\circ} 32^{\prime} 32^{\prime \prime}$ & 1786 \\
Waja & $39^{\circ} 36^{\prime} 09^{\prime \prime}$ & $12^{\circ} 18^{\prime} 03^{\prime \prime}$ & 1446 \\
Mohoni & $39^{\circ} 38^{\prime} 46^{\prime \prime}$ & $12^{\circ} 48^{\prime} 07^{\prime \prime}$ & 1767 \\
\hline
\end{tabular}

meteorological agency. The geographic coordinates of the stations are presented in Table 1. The World Meteorological Organization recommend using a period of more than 30 years data which is the optimal length to make climate study, and this study used from 1980 to 2012, which fulfills this recommendation. Each station's data were analyzed for the calculation of the mean monthly, seasonal, and annual values of precipitation and temperature, and then the calculation of the aridity indices was based on these mean values.

\section{Aridity indices}

Aridity is a lack of moisture and temporary reduction in the rainfall in an area (Maliva and Missimer 2012) and the increase in aridity represents a higher frequency of dry years over an area. Increasing aridity is a physical hazard affecting more negatively fields like agriculture and water supply. This is because of the fact that it can be a limiting factor for plant growth and distribution (Moral et al. 2015). Hence, a regional study of aridity needs appropriate aridity indices which can be defined as numerical indicators of the degree of dryness of the climate at a given location. Aridity indices classify the type of climate in relation to water availability (Moral et al. 2015). Moreover, aridity indices have greater value for following the effects of climate change on local water resources (Maliva and Missimer 2012).

Therefore, this study used De Martonne aridity index, Pinna combinative index, and Food and Agriculture Organization (FAO) aridity index to assess the spatial distribution of aridity indices. The first two aridity indices, based on temperature and precipitation, are commonly used in all over the world (Baltas 2007; Deniz et al. 2011; Croitoru et al. 2013; Hrnjak et al. 2013; Moral et al. 2015). Moreover, these aridity indices are applied in tropical and subtropical regions (Baltas 2007; Deniz et al. 2011). The FAO aridity index, which is based on rainfall and reference evapotranspiration, is also used frequently in assessing spatial patterns of aridity at a country or regional level (Nastos et al. 2013).

\section{De Martonne aridity index}

De Martonne, one of the best known and widely used indices (Shahid 2010; Croitoru et al. 2013; Hrnjak et al. 2013), created a climatic classification based on the duration of the aridity over the period year, which was used in this study. The higher the aridity indices classification of a region is, the greater the water resources variability (Deniz et al. 2011). This index can be computed at annual scale and also considers the shorter periods as the climate parameters vary significantly from one season to another or from month to month (Croitoru et al. 2013a, b; Moral et al. 2015).

The annual values of the De Martonne aridity index $\left(I_{\mathrm{DM}}\right)$ were calculated using Eq. 1. The climate type of a region can be classified according to the values obtained from $I_{\mathrm{DM}}$ calculation (Table 2).

$I_{\mathrm{DM} i}=\frac{P_{y i}}{T_{y i}+10}$

where $I_{\mathrm{DM} i}$ is De Martonne Aridity index at station $i, P_{y i}$ is annual precipitation is in $\mathrm{mm}$, and $T_{y i}$ is annual mean temperature in ${ }^{\circ} \mathrm{C}$ at station $i$.

The De Martonne aridity index for specific season was calculated using Eq. 2.

$I_{\mathrm{DM} s i}=\frac{4 \bar{P}_{s i}}{\bar{T}_{s i}+10}$

where $I_{\mathrm{DM} s i}$ is seasonal value of the De Martonne aridity index at station $i$ and the over bar $P_{s i}$ and $T_{s i}$ are mean seasonal precipitation and temperature, respectively, for each season at station $i$.

The De Martonne aridity index calculated using Eq. 3 was to identify the climate characteristic of a particular month. When the monthly De Martonne aridity index value is lower than 20, the lands need irrigation in that month (Baltas 2007).

$I_{\mathrm{DM} m i}=\frac{12 \bar{P}_{m i}}{\bar{T}_{m i}+10}$

Table 2 De Martonne aridity index classification (Baltas 2007)

\begin{tabular}{ll}
\hline Climate & Value of $I_{\mathrm{DM}}$ \\
\hline Dry & $I_{\mathrm{DM}}<10$ \\
Semi-dry & $10 \leq I_{\mathrm{DM}}<20$ \\
Mediterranean & $20 \leq I_{\mathrm{DM}}<24$ \\
Semi-humid & $24 \leq I_{\mathrm{DM}}<28$ \\
Humid & $28 \leq I_{\mathrm{DM}}<35$ \\
Very humid & $35 \leq I_{\mathrm{DM}} \leq 55$ \\
Extremely very humid & $I_{\mathrm{DM}}>55$ \\
\hline
\end{tabular}


Table 3 Climate according to the Pinna combinative index (Moral et al. 2015)

\begin{tabular}{ll}
\hline Climate & Value of $I_{\mathrm{P}}$ \\
\hline Dry & $I_{\mathrm{P}}<10$ \\
Semi-dry (Medi- & $10 \leq I_{\mathrm{P}}<20$ \\
$\quad$ terranean) & \\
Humid & $20 \leq I_{\mathrm{P}}<30$ \\
Very humid & $I_{\mathrm{P}} \geq 30$ \\
\hline
\end{tabular}

where $I_{\mathrm{DM} m i}$ is monthly value of the De Martonne aridity index at station $i$ and the over bar $P_{m i}$ and $T_{m i}$ are mean monthly precipitation and temperature, respectively, for the considered month at station $i$.

\section{Pinna combinative index}

Pinna combinative index $\left(I_{\mathrm{P}}\right)$ is another index, which is very important for agriculture and irrigation activities because it accounts the multiannual mean values of precipitation and air temperature of the driest month (Baltas 2007). The $I_{\mathrm{P}}$ was calculated using Eq. 4 . The four climate classifications according to the Pinna combinative index are shown in Table 3.

$I_{\mathrm{P} i}=\frac{1}{2}\left[\frac{P_{y i}}{T_{y i}+10}+\frac{12 \bar{P}_{d m i}}{\bar{T}_{d m i}+10}\right]$

where $I_{\mathrm{P} i}$ is Pinna combinative index at a given station $i, P_{y i}$ and $T_{y i}$ are annual precipitation in $\mathrm{mm}$ and mean temperature in ${ }^{\circ} \mathrm{C}$, respectively, at station $i$, the over bar $P_{d m i}$ and $T_{d m i}$ are precipitation and temperature means in the driest month at station $i$.

\section{FAO aridity index}

The FAO aridity index $\left(I_{\mathrm{FAO}}\right)$ computed as the ratio between mean annual precipitation $(P)$ and reference evapotranspiration $\left(E T_{o}\right)$ is shown in Eq. 5. Only Kobo, Maichew, and Chercher meteorological stations are considered for this aridity index computation because the remaining stations do not have recorded wind speed, sunshine hours and humidity data.

$I_{\mathrm{FAO}}=\frac{P}{E T_{o}}$

Penman-Monteith method (Eq. 6) was used to estimate $E T_{o}$ because the method is recommended as the sole standard method (Su et al. 2015). The detail procedure and explanation for Penman-Monteith can be found in FAO Irrigation and Drainage Paper No. 56 (McMahon et al. 2013). The
Table 4 Climate according to $I_{\mathrm{FAO}}$ (Moral et al. 2015)

\begin{tabular}{ll}
\hline Climate & Value of $I_{\mathrm{DM}}$ \\
\hline Hyper arid & $I_{\mathrm{FAO}}<0.05$ \\
Arid & $0.05 \leq I_{\mathrm{FAO}}<0.20$ \\
Semiarid & $0.20 \leq I_{\mathrm{FAO}}<0.50$ \\
Dry sub-humid & $0.50 \leq I_{\mathrm{FAO}}<0.65$ \\
Wet sub-humid & $0.65 \leq I_{\mathrm{FAO}} \leq 0.75$ \\
Humid & $I_{\mathrm{FAO}}>0.75$ \\
\hline
\end{tabular}

type of climate according to the FAO aridity index is shown in Table 4.

$E T_{o}=\frac{0.408 \Delta\left(R_{n}-G\right)+\Gamma \frac{900}{T+273} u_{2}\left(e_{s}-e_{a}\right)}{\Delta+\Gamma\left(1+0.34 u_{2}\right)}$

where $E T_{o}$ is reference evapotranspiration [mm day ${ }^{-1}$ ]; $R_{n}$ is net radiation at the crop surface $\left[\mathrm{MJ} \mathrm{m}^{-2} \mathrm{day}^{-1}\right] ; G$ is soil heat flux density $\left[\mathrm{MJ} \mathrm{m}^{-2} \mathrm{day}^{-1}\right] ; T$ is air temperature at $2 \mathrm{~m}$ height $\left[{ }^{\circ} \mathrm{C}\right] ; u_{2}$ is wind speed at $2 \mathrm{~m}$ height $\left[\mathrm{m} \mathrm{s}^{-1}\right] ; e_{s}$ is saturation vapor pressure $[\mathrm{kPa}] ; e_{a}$ is actual vapor pressure [kPa]; $\Delta$ is slope vapor pressure curve $\left[\mathrm{kPa}^{\circ} \mathrm{C}^{-1}\right]$ and $\Gamma$ is psychrometric constant $\left[\mathrm{kPa}^{\circ} \mathrm{C}^{-1}\right]$.

\section{Spatial estimation of aridity indices}

After the calculation of the aridity indices in each station of the study area, the spatial estimation of the indices from the stations' values were developed via interpolation method. Interpolation predicts values from a limited number of sample data points to predict unknown geographic point data. There are many interpolation methods to explain territorial variation, mainly grouped as deterministic methods and geostatistical methods (Croitoru et al. 2013). The deterministic methods are based on specified mathematical formulas, while the geostatistical method considers the spatial variation of any continuous variable based on statistical models. Comparing the two interpolation groups, predictions made using geostatistical algorithm interpolations are more accurate than deterministic methods (Moral 2010). However, due to the fewer number of stations, the inverse distance-weighted (IDW) deterministic interpolation method was applied which was also applied in spatial estimation of the climatic indices (Baltas 2007). The IDW is a method of interpolation that predicts cell values by averaging the values of sample data points in the vicinity of each processing cell. The nearest station has a greater weight compared to a station, which is at large distance to the interpolated point. The spatial estimation 
was done only for De Martonne aridity index and Pinna combinative index because of the limited number stations for spatial estimation of FAO aridity index.

\section{Result and discussion}

\section{Descriptive analysis of aridity indices}

Some descriptive statistics were analyzed to observe the data distribution of the aridity indices in Raya valley (Table 5). For the three aridity indices, the median and mean values are similar and the skewness values are low. This result is similar with the finding in Moral et al. (2015) which is an indicative that the data are from a normal distribution. Moreover,

Table 5 Descriptive statistics of the aridity indices

Table 6 Monthly DeMartonne aridity index value at each station
$S D$ standard deviation, $C V$ coefficient of variation the wide difference between minimum and maximum values and the high coefficients of variation for the three indices indicates the existence of high climatic spatial variability in Raya valley.

\section{De Martonne aridity index}

According to annual values of $I_{\mathrm{DM}}$, three meteorological stations located in the northern, eastern, and southern which are low elevated part of the valley showed as semi-dry conditions. While the meteorological stations at the mountainous area classified as humid condition. In regard to the winter seasonal value of $I_{\mathrm{DM}}$, only Korem station showed semi-dry condition with the value of 10.08 . The remaining meteorological stations are dry with range value of 2.99 , which is the driest at Chercher station to 8.53 at Waja station. In spring season, the more humid station is shown in the northern part of the study area and semi-humid in eastern part. In summer season, all stations are classified under semi-humid to extremely humid condition. During autumn season, the Alamata station is shown as dry condition and Korem station as semi-humid, while the remaining stations are classified as semi-dry condition. The $I_{\mathrm{DM}}$ value and elevation showed a direct relationship with coefficient of determination $\left(R^{2}\right)$ value of 0.7 . According to the $I_{\mathrm{DM} m}$ value, most of the stations showed the months except July and August are less than 20 which indicated that the lands need irrigation in these months (Table 6).

\section{Pinna combinative index}

The annual values of $I_{\mathrm{P}}$ in the stations ranged from 9.46 to 20.32 implying dry to humid climate condition. Mohoni and Chercher stations located at the northern and eastern part of the study area, respectively, are classified as dry. The remaining meteorological stations are classified under

\begin{tabular}{|c|c|c|c|c|c|c|c|c|}
\hline \multirow[t]{2}{*}{ Month } & \multicolumn{8}{|l|}{$I_{\mathrm{DM} m}$} \\
\hline & Alamata & Kobo & Korem & Maichew & Zobel & Chercher & Waja & Mohon \\
\hline Jan & 9.49 & 4.30 & 12.25 & 9.43 & 15.99 & 5.16 & 6.78 & 6.70 \\
\hline Feb & 5.03 & 2.56 & 2.25 & 3.09 & 4.75 & 1.83 & 13.40 & 16.77 \\
\hline Mar & 23.03 & 23.50 & 28.86 & 14.99 & 18.64 & 11.92 & 17.92 & 22.19 \\
\hline Apr & 32.25 & 31.92 & 38.71 & 26.61 & 33.38 & 16.49 & 26.99 & 31.33 \\
\hline May & 9.81 & 23.83 & 23.98 & 18.49 & 22.34 & 11.84 & 21.50 & 14.01 \\
\hline Jun & 3.95 & 3.47 & 8.66 & 7.32 & 4.84 & 3.45 & 10.25 & 7.18 \\
\hline Jul & 49.46 & 44.79 & 98.55 & 67.20 & 58.80 & 45.15 & 38.42 & 20.35 \\
\hline Aug & 93.10 & 81.19 & 136.98 & 96.83 & 108.23 & 74.57 & 59.78 & 47.23 \\
\hline Sep & 14.92 & 20.00 & 32.53 & 32.64 & 39.79 & 13.03 & 22.99 & 26.37 \\
\hline Oct & 5.57 & 11.61 & 17.63 & 18.51 & 21.88 & 5.70 & 8.14 & 4.87 \\
\hline Nov & 8.24 & 7.94 & 25.48 & 16.16 & 18.53 & 18.34 & 5.38 & 7.24 \\
\hline Dec & 11.21 & 10.70 & 18.12 & 12.98 & 5.96 & 3.54 & 6.05 & 1.68 \\
\hline
\end{tabular}


semi-dry condition except Korem, located in the eastern mountainous part of the study area, which is classified as humid but its value is more closed to semi-dry condition.

\section{FAO aridity index}

According to the $I_{\mathrm{FAO}}$ value, Kobo and Chercher meteorological stations showed as semiarid climate condition range from 0.3 to 0.34 , while the Maichew at station at mountain area showed a dry sub-humid with value of 0.51 . This indicates that the $I_{\mathrm{FAO}}$ value increases to the mountain station which is similar to the $I_{\mathrm{DM}}$ and $I_{\mathrm{P}}$. Overall, a high coefficient of determination was noticed among the three indices (Fig. 2).

\section{Spatial distribution De Martonne aridity index}

According to the spatial distribution of the annual $I_{\mathrm{DM}}$ in Raya valley (Fig. 4), all the range of $I_{\mathrm{DM}}$ categories are found in the study area except dry and extremely very humid conditions. The spatial distribution of the $I_{\mathrm{DM}}$ of the annual values revealed that the semi-dry zones include from Raya Azobo and Kobo zones. Values of the $I_{\mathrm{DM}}$ increase to the east of Ofla and Endamohoni zones. The very humid condition which covers $3.2 \%$ of the study area is found in high elevation zones along the eastern part of the study area where the highest annual precipitation is recorded. The increase in $I_{\mathrm{DM}}$ value is in line with the spatial distribution of precipitation which is an indication that they have direct relationship.

The seasonal spatial distribution of $I_{\mathrm{DM}}$ is shown in Fig. 3. During the winter time, almost all the study areas $(97.7 \%)$ are of dry climate condition. The spatial distribution of $I_{\mathrm{DM}}$ in the spring season is similar to the annual pattern except the very humid climate condition. Next to annually, the highest spatial variability with categories range from semiarid to humid is shown in spring season. The semi-dry climate condition is dominant $(84.8 \%)$ in the autumn season, and the summer season is dominantly with very humid climate conditions.

According to the monthly $I_{\mathrm{DM}}$, the whole study area needs irrigation in January, February, June, October, and December. The study area also needs irrigation in the months of March, May, September, and November with 48.5\%, 80.8\%, $22.7 \%$, and $93.1 \%$ coverage, respectively. Very small area (3.1\%) which is located in eastern part of the study area also needs irrigation in April. The highest spatial variability is shown in April, July, and September in which categories range from semi-dry to extremely very humid. The monthly value of $I_{\mathrm{DM}}$ indicates that the area needs irrigation in most of the months with different percentage coverage (Table 7).

Over all, the annual, seasonal, and monthly aridity indices of $I_{\mathrm{DM}}$ showed variability of their values which indicated
Fig. 2 Annual coefficient of determination between the indices of DeMartonne aridity index and Pinna combinative index (left), DeMartonne aridity index and FAO aridity index (center), Pinna combinative index, and FAO aridity index (right)

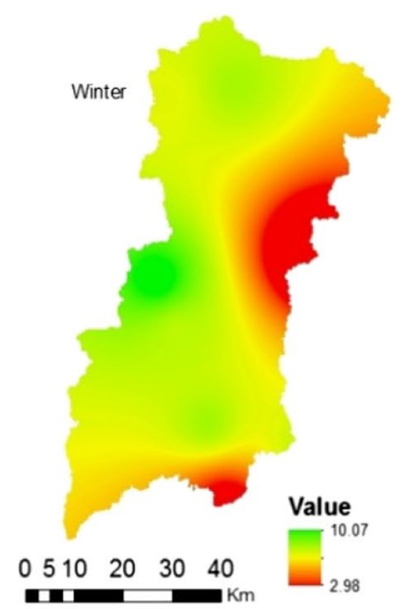

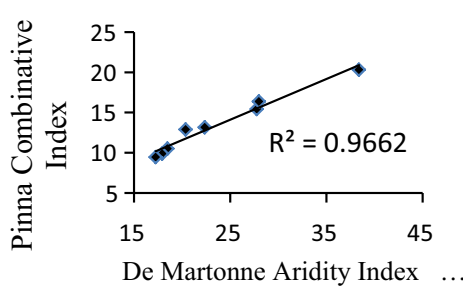
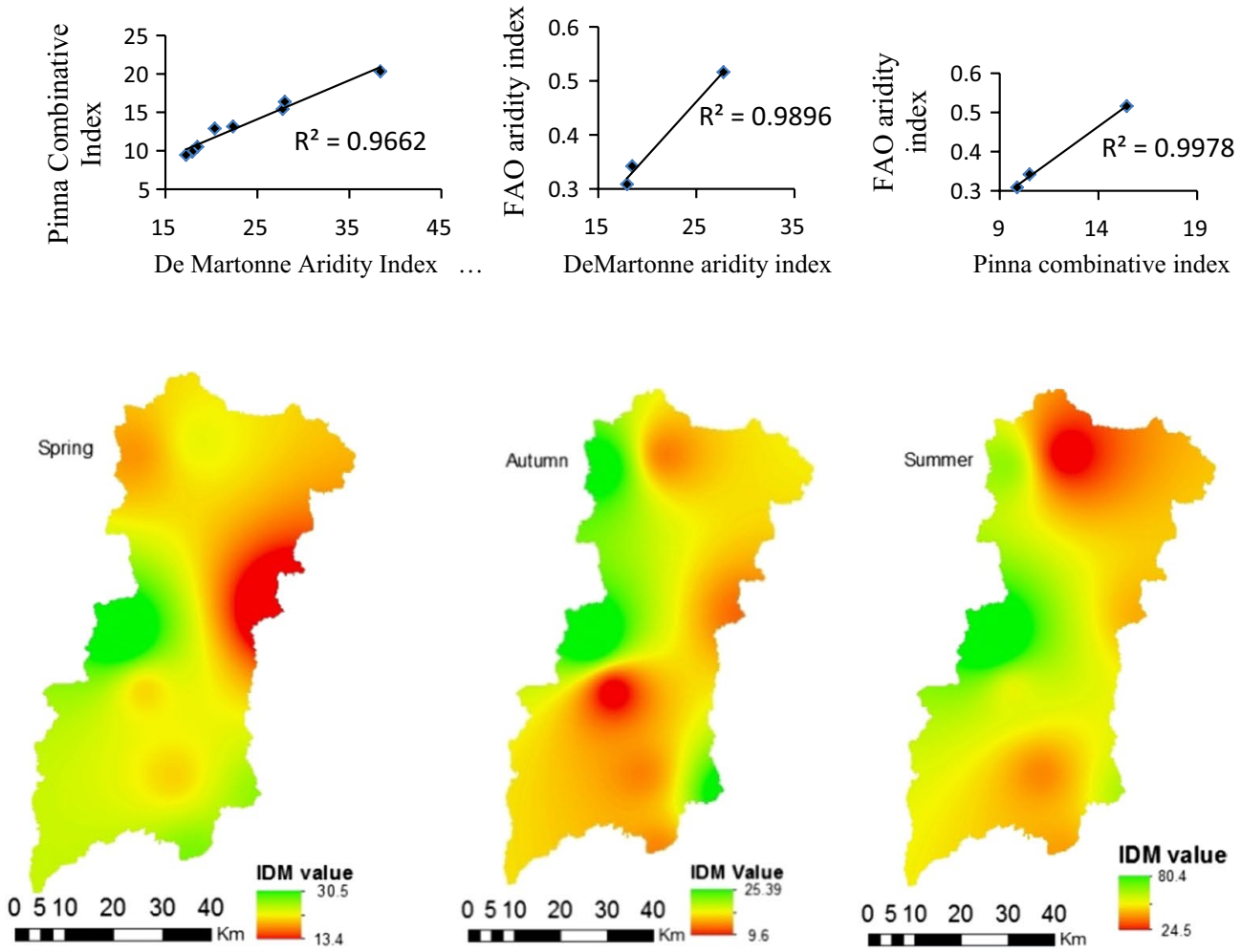

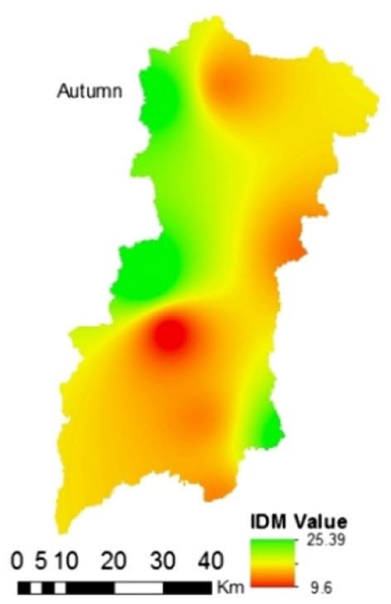

Fig. 3 Seasonal spatial distribution of the De Martonne aridity index

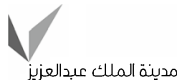

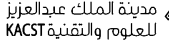
Springer 
Table 7 Percentage of Raya valley within each climate category according to the monthly DeMartonne aridity index

\begin{tabular}{lllllllllllll}
\hline Climate & Jan & Feb & Mar & Apr & May & Jun & Jul & Aug & Sep & Oct & Nov & Dec \\
\hline D & 84.7 & 77.4 & 0 & 0 & 0.1 & 99.4 & 0 & 0 & 0 & 66.9 & 34.7 & 65.1 \\
SD & 15.3 & 22.6 & 48.5 & 3.1 & 80.7 & 0.6 & 0 & 0 & 22.7 & 32.8 & 58.8 & 34.9 \\
M & 0 & 0 & 40.4 & 6.6 & 19.2 & 0 & 1.6 & 0 & 34.5 & 0.4 & 5.1 & 0 \\
SH & 0 & 0 & 11.1 & 20.1 & 0 & 0 & 2.8 & 0 & 23.6 & 0 & 1.4 & 0 \\
H & 0 & 0 & 0 & 64.0 & 0 & 0 & 7.5 & 0 & 18.5 & 0 & 0 & 0 \\
VH & 0 & 0 & 0 & 6.2 & 0 & 0 & 55.4 & 4.0 & 0.8 & 0 & 0 & 0 \\
EVH & 0 & 0 & 0 & 0 & 0 & 0 & 32.8 & 96.0 & 0 & 0 & 0 & 0 \\
\hline
\end{tabular}

$D$ dry, $S D$ semi-dry, $M$ Mediterranean, $S H$ semi-humid, $H$ humid, $V H$ very humid, $E V H$ extremely very humid
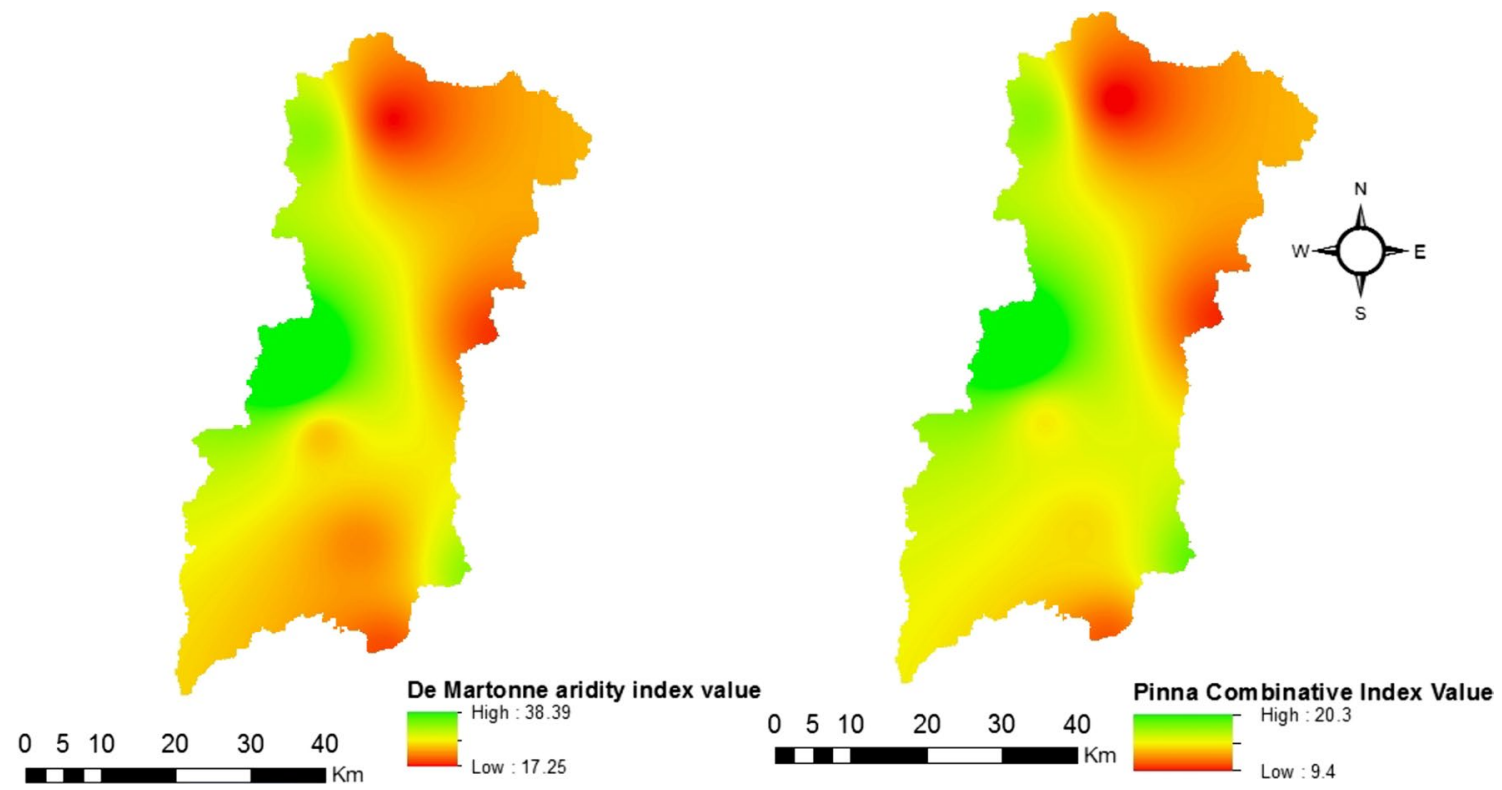

Fig. 4 Spatial distribution of the De Martonne aridity index (left), the Pinna combinative index (right)

the study area is characterized by high spatial variability of aridity index. This can be helpful for following the effects of climate change on the local water resource variability.

\section{Spatial distribution Pinna combinative index}

According to the spatial $I_{\mathrm{P}}$ value, the dry (1.6\%) and semidry $(98 \%)$ climate conditions prevail in the study area and only about $0.4 \%$ of the area are under humid condition. The spatial distribution of the $I_{\mathrm{P}}$ in Raya valley is shown in Fig. 4 revealed that the semi-dry zones covered some proportions from Raya Azobo and Kobo zones, which is similar with $I_{\mathrm{DM}}$ pattern. Moreover, values of the $I_{\mathrm{P}}$ increase to the east of Ofla and Endamohoni zones. The humid condition of the study area is also found in high elevation zones along the eastern part of Raya valley where the highest annual precipitation is recorded. The spatial distributions of $I_{\mathrm{P}}$ are similar to those obtained for the annual $I_{\mathrm{DM}}$ though more diversified distribution of climate types in the study area is obtained using the $I_{\mathrm{DM}}$.

\section{Conclusion}

The goal of this study is to analyze spatial distribution of climatic characterization using climate indices. For this purpose, an analysis of aridity is presented using climate indices over Raya valley based on meteorological data from eight stations. Spatial distribution of the aridity indices was performed throughout the studied region. The station values of three indices indicated a high coefficient of determination, which in common reveals area prone to dry and semi-dry risk. The spatial distribution of De Martonne index and Pinna combinative index was similar. However, evaluating the results of these two indices, the De Martonne 
index was found more appropriate for the considered area since it defines more precisely the climate of each location using seven classes and it can be computed at specific season and month. The spatial distribution of the De Martonne index emphasized increased irrigation requirements in the northern east part of the study area. The study area needs irrigation in most of the months with different percentage coverage. Therefore, it is helpful to consider aridity analysis for the water resources utilization and irrigation systems of the study area. Increasing in aridity implies that drought may persist, and it is important to predict the future aridity indices of the study area.

Acknowledgements The authors gratefully acknowledge Mekelle University for the research fund through the recurrent research project (CRPO/I-GEOS/002/08). The National Meteorology Agency (NMA) of Ethiopia and Tigray Regional Meteorology Agency are also gratefully acknowledged for providing the meteorological data.

Open Access This article is distributed under the terms of the Creative Commons Attribution 4.0 International License (http://creativeco mmons.org/licenses/by/4.0/), which permits unrestricted use, distribution, and reproduction in any medium, provided you give appropriate credit to the original author(s) and the source, provide a link to the Creative Commons license, and indicate if changes were made.

\section{References}

Arora VK (2002) The use of the aridity index to assess climate change effect on annual runoff. J Hydrol 265(1-4):164-177

Baltas E (2007) Spatial distribution of climatic indices in northern Greece. Meteorol Appl 14:69-78

Croitoru AE, Piticar A, Imbroane AM, Burada DC (2013) Spatiotemporal distribution of aridity indices based on temperature and precipitation in the extra-Carpathian regions of Romania. Theor Appl Climatol 112:597-607

Deniz A, Toros H, Incecik S (2011) Spatial variations of climate indices in Turkey. Int J Climatol 31(3):394-403

Fenta AA, Kifle A, Gebreyohannes T, Hailu G (2015) Spatial analysis of groundwater potential using remote sensing and GIS-based multi-criteria evaluation in Raya Valley, northern Ethiopia. Hydrogeol J 23(1):195-206

Hrnjak I, Lukić T, Gavrilov MB, Marković SB, Unkašević M, Tošić I (2013) Aridity in Vojvodina, Serbia. Theor Appl Climatol 115(1-2):323-332

IPCC (2007) Climate change 2007: mitigation. Contribution of Working Group III to the fourth assessment report of the Intergovernmental Panel on Climate Change. Cambridge University Press, Cambridge

IPCC (2012) Managing the risks of extreme events and disasters to advance climate change adaptation: a special report of working groups I and II of the intergovernmental panel on climate change. Cambridge University Press, Cambridge

Kenny G, Ye W, Flux T, Warrick RA (2001) Climate variations and New Zealand agriculture: the CLIMPACTS system and issues of spatial and temporal scale. Environ Int 27(2-3):189-194

Maliva RG, Missimer TM (2012) Arid lands water evaluation and management. Environ Sci Eng 3(1948):806

McMahon TA, Peel MC, Lowe L, Srikanthan R, McVicar TR (2013) Estimating actual, potential, reference crop and pan evaporation using standard meteorological data: a pragmatic synthesis. Hydrol Earth Syst Sci 17:1331-1363

Moral FJ (2010) Comparison of different geostatistical approaches to map climate variables: application to precipitation. Int J Climatol 30(4):620-631

Moral FJ, Rebollo FJ, Paniagua LL, García-Martín A, Honorio F (2015) Spatial distribution and comparison of aridity indices in Extremadura, southwestern Spain. Theor Appl Climatol. https:// doi.org/10.1007/s00704-015-1615-7

Nastos PT, Politi N, Kapsomenakis J (2013) Spatial and temporal variability of the aridity index in Greece. Atmos Res 119:140-152

Shahid S (2010) Spatio-temporal variation of aridity and dry period in terms of irrigation demand in Bangladesh. American-Eurasian J Agric Environ Sci 7(4):386-396

Su X, Singh VP, Niu J, Hao L (2015) Spatiotemporal trends of aridity index in Shiyang River basin of northwest China. Stoch Environ Res Risk Assess 29(6):1571-1582

Zubler EM, Scherrer SC, Croci-Maspoli M, Liniger MA, Appenzeller C (2014) Key climate indices in Switzerland; expected changes in a future climate. Clim Change 123(2):255-271

Publisher's Note Springer Nature remains neutral with regard to jurisdictional claims in published maps and institutional affiliations. 